\title{
"The marketing channels for fresh fruit bunches at farmers palm oil plantation"
}

\begin{tabular}{|c|c|}
\hline AUTHORS & $\begin{array}{l}\text { Sumitro Sarkum iD https://orcid.org/0000-0001-8752-2669 } \\
\text { R https://publons.com/researcher/1366314/sumitro-sarkum/ } \\
\text { Novilda Elizabeth Mustamu id https://orcid.org/0000-0003-2800-8920 } \\
\text { Gomal Juni Yanris }\end{array}$ \\
\hline ARTICLE INFO & $\begin{array}{l}\text { Sumitro Sarkum, Novilda Elizabeth Mustamu and Gomal Juni Yanris (2020). The } \\
\text { marketing channels for fresh fruit bunches at farmers palm oil plantation. } \\
\text { Innovative Marketing , 16(4), 139-144. doi:10.21511/im.16(4).2020.12 }\end{array}$ \\
\hline DOI & http://dx.doi.org/10.21511/im.16(4).2020.12 \\
\hline RELEASED ON & Wednesday, 23 December 2020 \\
\hline RECEIVED ON & Monday, 14 September 2020 \\
\hline ACCEPTED ON & Saturday, 19 December 2020 \\
\hline LICENSE & $\begin{array}{l}(c) \text { EY } \\
\text { This work is licensed under a Creative Commons Attribution } 4.0 \text { International } \\
\text { License }\end{array}$ \\
\hline JOURNAL & "Innovative Marketing " \\
\hline ISSN PRINT & $1814-2427$ \\
\hline ISSN ONLINE & $1816-6326$ \\
\hline PUBLISHER & LLC "Consulting Publishing Company "Business Perspectives" \\
\hline FOUNDER & LLC "Consulting Publishing Company "Business Perspectives" \\
\hline
\end{tabular}

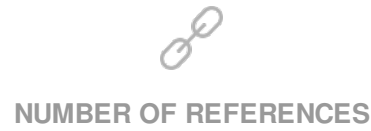

21
NUMBER OF FIGURES

1
NUMBER OF TABLES

2

(C) The author(s) 2021. This publication is an open access article. 


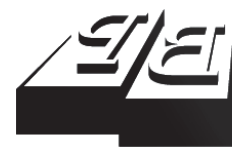

\section{BUSINESS PERSPECTIVES}

LLC "CPC "Business Perspectives" Hryhorii Skovoroda lane, 10, Sumy, 40022, Ukraine www.businessperspectives.org
Received on: $14^{\text {th }}$ of September, 2020 Accepted on: $19^{\text {th }}$ of December, 2020 Published on: $23^{\text {rd }}$ of December, 2020

(C) Sumitro Sarkum, Novilda Elizabeth Mustamu, Gomal Juni Yanris, 2020

Sumitro Sarkum, Mgr., Dr., Faculty of Economics and Business, State Universitas Labuhanbatu, Rantauprapat, Indonesia. (Corresponding author)

Novilda Elizabeth Mustamu, Mgr., Faculty of Science and Technology, State Universitas Labuhanbatu, Indonesia.

Gomal Juni Yanris, Mgr., Faculty of Science and Technology, State Universitas Labuhanbatu, Indonesia.
Sumitro Sarkum (Indonesia), Novilda Elizabeth Mustamu (Indonesia),

Gomal Juni Yanris (Indonesia)

\section{THE MARKETING CHANNELS FOR FRESH FRUIT BUNCHES AT FARMERS PALM OIL PLANTATION}

\begin{abstract}
The aim of this study is to determine the marketing channels for Fresh Fruit Bunches (FFB) of palm oil plantations of farmers in Labuhanbatu Regency, which are carried out by traders, causing price fluctuations. The research method was based on library research, field research and qualitative analysis of primary data collected through interviews with a number of farmers, collector traders, and palm oil mills in Labuhanbatu and surrounding areas. The results of this study showed the real price fluctuations in the FFB trade in Labuhanbatu Regency, while the marketing function of farmers and the supply chain showed the same thing, even though they had different expenses for that function. Whereas the share margin found in the findings of this study was $62 \%$ with a marketing efficiency level of $30 \%$. The study also found that FFB marketing channels in Labuhanbatu District had eight channel levels, but this research only confirmed one level, namely the third marketing channel. Thus, this study suggests that follow-up research will explore the remaining seven channels with similar and different topics and issues.
\end{abstract}

\section{Keywords}

farmers, fresh fruit bunches (FFB), marketing channel, supply chain

JEL Classification M31, D43

\section{INTRODUCTION}

There are several Crude Palm Oil (CPO) producing countries, and one of the biggest is Indonesia. In Indonesia, there are several provinces that produce oil palm plantations, and one of them is North Sumatra Province, and in this, there are several CPO producing districts of oil palm plantations, one of which is Labuhanbatu Regency. Whereas the statement of the Fresh Fruit Bunches (FFB) and CPO purchase price, which is set per week by the government through the North Sumatra Plantation Office, only accommodates the CPO and FFB prices of palm oil produced by plasma farmers, while for independent farmers and companies are not set (Naibaho \& N, 2019). Plasma estate is a Core Estate and Smallholders with a development pattern in new open land areas with large plantations as the core that builds and guides smallholders around the company called plasma in a mutually beneficial, whole and sustainable cooperation system (Core estate and smallholder, 2017).

This research was conducted to find out how much influence made the marketing channels of Fresh Fruit Bunches (FFB) on the selling price of FFB palm oil plantation at farmers in Labuhanbatu Regency. Some conditions had been mentioned to be the factors in the decline in the purchase value of FFB in farmers, including a decrease in Indonesia's $\mathrm{CPO}$ export sales values abroad, many oil palm mills did not have 
nucleus estates and did not want to buy directly from farmers, however, they instead relied on the supply of raw materials from collector traders and the number of mandatory deductions applied (Subagyo, 2019). Therefore, it is necessary to know directly whether this phenomenon is really affecting or if there are other phenomena that cause a difference in the price of the FFB marketing channel for farmers (Ismail et al., 2020).

\section{LITERATURE REVIEW AND THEORETICAL FRAMEWORK}

According to the agricultural statistics, in 2019, the total area of public oil palm plantations, state plantations and private plantations in northern Sumatra was $1,595,572$ ha (Susanti \& Waryanto, 2018). And there are four managements of palm oil in Labuhanbatu Regency, the first is managed by a state-owned plantation company covering an area of 53,838 hectares with FFB production of 154,068 tons/year; secondly, managed by a national private plantation company, with the same income as Labuhanbatu District, covering 223,678 ha with FFB production of 1,044,351 tons/year; third, managed by foreign private plantation companies covering an area of 24,002 ha with FFB production of 108,118 tons/year, and the fourth is managed independently by the community around 32,449 ha with FFB production of 503,100,045 tons annually (Statistic Perkebunan Prov. SU, 2019). From the total area of oil palm plantations, Labuhanbatu District produces CPO from FFB as much as one million liters annually (Hamdani, 2019).

The most used marketing channel by farmers is Collecting Traders and the intermediary agent is part of the FFB marketing channel that carries out business activities with palm oil processing companies (Sirait, 2020). The function of collecting traders as a marketing channel entangled farmers in selling FFB with seeing a different price level which is given of palm oil processing companies as a part of marketing institutions. Collector traders have a role in assisting oil palm companies to meet the fruit needs of $\mathrm{CPO}$ production through

Table 1. Differences in profit sharing between FFB sale and purchase

\begin{tabular}{|c|c|c|c|}
\hline Publication & Authors & Marketing flow & Share margin \\
\hline $\begin{array}{l}\text { Agricultural Scientific } \\
\text { Journal }\end{array}$ & Pratama et al. (2016) & Farmers $\rightarrow$ Traders Collectores $\rightarrow$ Palm Oil Mill & $\begin{array}{l}\text { Share Margin received by farmers } \\
\text { is } 73.03 \%\end{array}$ \\
\hline $\begin{array}{l}\text { Wahana Innovation: } \\
\text { Journal of Research and } \\
\text { Community Service UISU }\end{array}$ & $\begin{array}{l}\text { Harahap, Simanullang, } \\
\text { \& Romadon (2017) }\end{array}$ & $\begin{array}{l}\text { Farmers } \rightarrow \text { Traders Collectors } \rightarrow \text { Middle } \\
\text { traders } \rightarrow \text { Palm Oil Mill } \\
\text { Farmers } \rightarrow \text { middle Traders } \rightarrow \text { Palm Oil Mill }\end{array}$ & $\begin{array}{l}\text { Share Margin received by farmers } \\
\text { is } 34.4 \% \text {. Share margin received by } \\
\text { farmers is } 37.3 \%\end{array}$ \\
\hline Agrica Ekstensia Jurnal & Rahmanta (2017) & $\begin{array}{l}\text { Farmers } \rightarrow \text { Agents } \rightarrow \text { RAM } \rightarrow \text { Palm Oil Mill } \\
\text { Farmers } \rightarrow \text { Palm Oil Mill }\end{array}$ & $\begin{array}{l}\text { Share Margin received by farmers } \\
\text { is } 72.96 \% \text {. Share margin received } \\
\text { by farmers is } 100 \%\end{array}$ \\
\hline $\begin{array}{l}\text { TABARO Agriculture } \\
\text { Science Journal }\end{array}$ & $\begin{array}{l}\text { Sumiati, Rusida, \& } \\
\text { Idawati (2017) }\end{array}$ & Farmers $\rightarrow$ Traders Collectors $\rightarrow$ Palm Oil Mill & $\begin{array}{l}\text { Share Margin received by farmers } \\
\text { is } 72 \%\end{array}$ \\
\hline $\begin{array}{l}\text { AGRARIS: Journal of } \\
\text { Agribusiness and Rural } \\
\text { Development Research }\end{array}$ & $\begin{array}{l}\text { Sumartono, Badrudin, } \\
\& \text { Suryanty (2018) }\end{array}$ & $\begin{array}{l}\text { Farmers } \rightarrow \text { trader collectors } \rightarrow \text { Palm Oil Mill } \\
\text { Farmers } \rightarrow \text { Farmers group } \rightarrow \text { Palm Oil Mill }\end{array}$ & $\begin{array}{l}\text { The value of farmer share received } \\
\text { by farmers amounted to } 72.68 \% \text {. } \\
\text { Farmer share value received by } \\
\text { farmers is } 81.03 \%\end{array}$ \\
\hline Agriprimatech & $\begin{array}{l}\text { Pinem, Safrida, \& } \\
\text { Nasution (2018) }\end{array}$ & $\begin{array}{l}\text { Farmers } \rightarrow \text { Palm Oil Mill } \\
\text { Farmers } \rightarrow \text { Agent Small } \rightarrow \text { Agent big } \rightarrow \text { Palm Oil } \\
\text { Mill }\end{array}$ & $\begin{array}{l}\text { Farmers ,Small Agents' Big Agents } \\
\text {,Farmers' Palm Oil Mill Share by } \\
100 \% \text {. Farmers' Share by } 80 \% \text {. }\end{array}$ \\
\hline Magrobis Journal & Nugroho (2015) & $\begin{array}{l}\text { Farmers } \rightarrow \text { Collector } \rightarrow \text { Retail } \rightarrow \text { Palm Oil Mill } \\
\text { Farmers } \rightarrow \text { Collector } \rightarrow \text { Wholesalers } \rightarrow \\
\text { Retailer } \rightarrow \text { Palm Oil Mill }\end{array}$ & $\begin{array}{l}\text { The two-level marketing channel } \\
\text { for farmers is } 76.15 \% \text {, the three- } \\
\text { level marketing channel, the share } \\
\text { received by farmers is } 73.53 \%\end{array}$ \\
\hline Journal RAT & $\begin{array}{l}\text { Wulandari \& Salman } \\
\text { (2014) }\end{array}$ & Farmers $\rightarrow$ Collector $\rightarrow$ Palm Oil Mill & $\begin{array}{l}\text { Share margin obtained by farmers } \\
\text { is } 69.23 \%\end{array}$ \\
\hline Pekbis Jurnal & Tety et al. (2013) & Farmers $\rightarrow$ Collector Trader $\rightarrow$ Palm Oil Mill & $\begin{array}{l}\text { The average marketing margin } \\
\text { from Palm Oil Mill to farmers is } \\
85.05 \% \text {. }\end{array}$ \\
\hline $\begin{array}{l}\text { Journal of Agricultural } \\
\text { Economics and } \\
\text { Development }\end{array}$ & Noor (2013) & $\begin{array}{l}\text { Farmers } \rightarrow \text { Cooperation } \rightarrow \text { Palm Oil Mill } \\
\text { Farmers } \rightarrow \text { Collector Traders } \rightarrow \text { Palm Oil Mill }\end{array}$ & $\begin{array}{l}\text { An average share margin of } \\
78.69 \% \text { was received by farmers. } \\
\text { An average share margin of } \\
72.72 \% \text { was received by farmers }\end{array}$ \\
\hline
\end{tabular}


the mail order paying agent business. According to Nasution (2016) a common process for mail order paying holders can collect directly from farmers or use a collecting agent. There is also a paying agent who pays directly for each FFB that enters the palm oil mill using the order letter paying own, then three, four, or five days later the order letter paying holder pays the FFB that has been entered by the paying agent according to the agreed price. The presence of collector traders surfaces in the business of buying and selling FFB because of order letters provided so that traders gather FFB to meet company needs. Collectors receive compensation from consumers in the form of marketing margins. Due to the marketing channels element in the purchase of FFB, then any marketing costs are one of the elements of the effects the price of FFB in farmers (Fadilah et al., 2018). Some articles talk about the differences in the following prices, marketing channels can be seen in Table 1 .

From the results of the research differences in Table 1 , it can be seen that if the distribution of profits to farmers on average was $88 \%$, then the average profit-sharing was $76.15 \%$ with a marketing cost of $12 \%$. Whereas for the marketing cost the lowest from the marketing channel was in the marketing channel is Farmers to Collector, then collector to Traders Medium and the next are medium traders to Palm Oil Mill is amounting to $34.4 \%$ and with marketing costs of $65.6 \%$. The difference in research in table 1 explains that the distribution of profits made by the marketing channels is one of the factors that influence the fluctuation of FFB prices. The difference in research in table 1 explains that the distribution of profits made by the supplier is one of the factors that influence the fluctuation of FFB prices. Therefore it is necessary to know what is the form of the FFB Marketing Channels system in Labuhanbatu Regency can be seen in Figure 1.

\section{METHODS}

This study was based on library research and field research and qualitative analysis of primary data

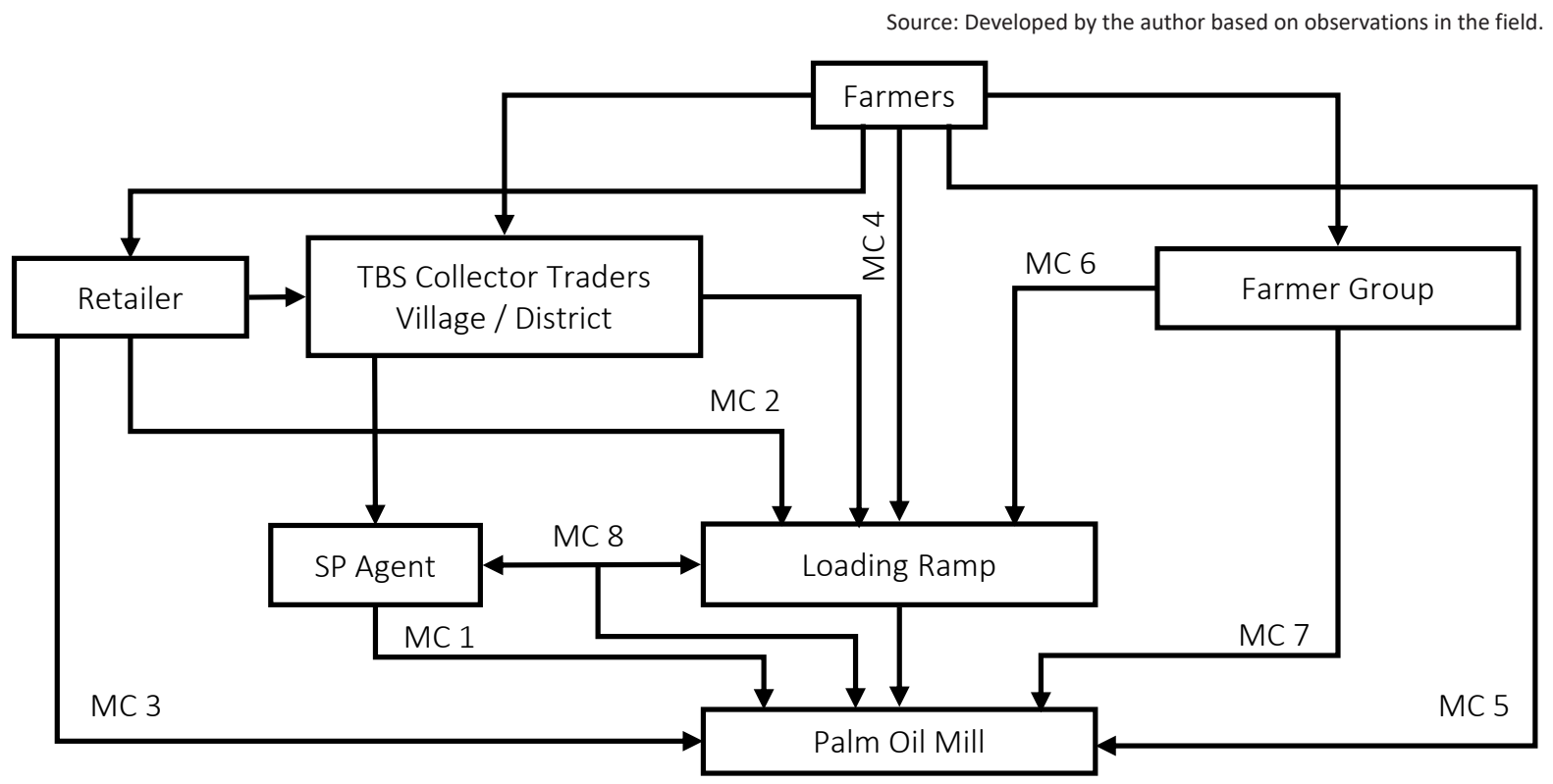

Note: Information:

Marketing Channel S1: Farmers $\rightarrow$ Retailer $\rightarrow$ SP Agent $\rightarrow$ Palm Oil Mill (Level two level channel)

Marketing Channel S2: Farmers $\rightarrow$ Retailer $\rightarrow$ Loading Ramp $\rightarrow$ Palm Oil Mill (Level two level channel)

Marketing Channel S3: Farmers $\rightarrow$ Retailer $\rightarrow$ Palm Oil Mill (One level channel)

Marketing Channel S4: Farmers $\rightarrow$ Loading Ramp $\rightarrow$ Palm Oil Mill (One level channel)

Marketing Channel S5: Palm Oil Mill (Zero level channel)

Marketing Channel S6: Farmers $\rightarrow$ Farmer Group $\rightarrow$ Loading Ramp $\rightarrow$ Palm Oil Mill (Level two level channel)

Marketing Channel S7: Farmers $\rightarrow$ Farmer Group $\rightarrow$ Palm Oil Mill (One level channel)

Marketing Channel S8: Farmers $\rightarrow$ Retailer $\rightarrow$ FFB Collector $\rightarrow$ SP Agent/Loading Ramp $\rightarrow$ Palm Oil Mill (Level tree level channel)

Figure 1. FFB Marketing Channels in Labuhanbatu Regency 
collected through interviews with a number of farmers, collector traders, and palm oil mills in Labuhanbatu and surrounding areas. Secondary data presented in this study mainly came from reports and databases published by the Department of Agriculture (Data Luas Areal, Produksi dan Produktivitas Perkebunan Rakyat Tahun 2019 Komoditas Kelapa Sawit, 2019). The FFB price questionnaire was designed to obtain numerical data on FFB production, prices and marketing. Farmers and traders selected randomly were interviewed in person. This research was conducted from March 2019 to September 2019 for 215 farmers, 224 micro traders and 15 small traders distributed in 9 districts in Labuhanbatu Regency.

\section{RESULTS AND DISCUSSION}

Interview findings suggested that $92 \%$ of farmers who owned oil palm plantations were less than 4 ha, $73 \%$ sell FFB to micro traders at an average price of IDR $736 / \mathrm{kg}$ and $73.5 \%$ stated the price was not appropriate given, $98.6 \%$ did not know the price-fixing set by the government, $76.7 \%$ did not know the cause of the instability of FFB prices, $97.7 \%$ had $1-4$ workers, $91.2 \%$ had a sales turnover of less than IDR 300,000,000/year, while for marketing costs 99.5\% of farmers were burdened with transportation, labor, depreciation, warehousing, sorting, risk management, market information and other costs, with costs charged varying from IDR $30 / \mathrm{kg}$ - 300/kg with an average of IDR $195 / \mathrm{kg}$. Whereas for the price of fertilizers and pesticides $64.2 \%$ of farmers stated that the prices of fertilizers and pesticides were not affordable. 96.3\% Farmers also did not know the oil palm association or organizations, $94.4 \%$ stated they did not feel the benefits,
94.4\% never received expert services, $99.5 \%$ never received capital services from banks, oil palm plantations had 13-year age in average with an average monthly production of $5,960.59 \mathrm{~kg} /$ month, $88.8 \%$ of farmers were male, the average age of 40 years and an average length of farming was 14 years, and 25 questionnaires were given to respondents for each point in nine districts of the total number of respondents. The following can be seen in table 2 .

While the findings of interviews with micro traders stated that $74.2 \%$ sold FFB collected to large traders or Loading Ramp with an average price of IDR $1,187 / \mathrm{kg}$ and the average buying price of farmers FFB $861 / \mathrm{kg}$, and for pricing information set by the government $88.4 \%$ did not know this, $90.2 \%$ had a workforce of $1-4$ people, $79.5 \%$ had a turn over sales of less than IDR 300,000,000/year, while for marketing costs as much as $92.9 \%$ of traders were burdened with transportation, labor, depreciation, warehousing, sorting, risk management, market information and other costs, with fees charged varying from IDR 20/kg-250/kg with an average of IDR $166 / \mathrm{kg}$. $84.4 \%$ of micro traders also did not know the oil palm association or organizations, $88.8 \%$ of business operators were male, the average length of FFB trading was 8 years, the average sales were $46,080.34 \mathrm{~kg} / \mathrm{month}$, and an average of 24 questionnaires was given to respondents for each point in nine districts of the total number of respondents.

While the findings of interviews with small traders stated that $53.3 \%$ sold the collection of FFB to large traders at an average price of IDR 869/ $\mathrm{kg}$, IDR $650 / \mathrm{kg}$ provides prices to micro traders who collect FFB farmers and IDR 678/kg if farmers come directly to sell their FFB and for pricing information set by the government $86.7 \%$ did not

Table 2. Number of traders and Palm Oil Mill and average FFB production in Labuhanbatu Regency

Source: http://disbun.sumutprov.go.id/

\begin{tabular}{l|c}
\hline \multicolumn{1}{c}{ Marketing location (district) } & Smallholder average production (Year/Ha/Kg) \\
\hline Bilah Barat & 3.564 .06 \\
Bilah Hilir & 3.680 .04 \\
\hline Bilah Hulu & 2.895 .00 \\
\hline Pangkatan & 3.922 .00 \\
\hline Panai Hilir & 1.854 .59 \\
Panai Hulu & 3.667 .30 \\
\hline Panai Tengah & 2.941 .41 \\
\hline Rantau Utara & 3.968 .27 \\
\hline Rantau Selatan & 3.3220 .88 \\
\hline
\end{tabular}


know this, $80 \%$ did not have a sale and purchase permit, $73.3 \%$ had a workforce of $1-4$ people and the rest 5-19 people, $66.7 \%$ had a sales turnover of less than IDR 300,000,000/year, while for marketing costs as much as $77.8 \%$ of merchants were burdened with transportation, labor, depreciation, warehousing, sorting, risk management, market information and other costs, with fees charged varying from IDR $30 / \mathrm{kg}-70 / \mathrm{kg}$. $86.7 \%$ of the small traders also did not know the oil palm association or organizations, $100 \%$ of business operators were male with an average age of 40 years, the length of time traded FFB is 9 years in average, the average sales of $364,694.07 \mathrm{~kg} / \mathrm{month}$, and for the distribution of questionnaires only done in four points from nine points due to the unavailability of traders operating in other areas to be interviewed. From the description of these findings, the FFB supply chain in Labuhanbatu District can be analyzed that prices vary according to the location and place of purchase or location of the farm- er's farm. Likewise, the distribution of profits in carrying out marketing functions in supply chain marketing operations showed the same thing,

The FFB marketing channel in Labuhanbatu Regency on the results of this study did not involve all channels of this level due to the absence of information provided by the respondents due to an element of confidentiality which they considered could not be consumed by the public. If seen from the marketing efficiency in the marketing channel which was based on the interview findings adjusted in Figure 1, it can be explained that the applicable marketing channel in Labuhanbatu Regency was in the Marketing Channel S3: Farmers $\rightarrow$ Retailer $\rightarrow$ Palm Oil Mill (One level channel). Therefore, it was known that the share margin received by farmers was $62 \%$ and had a marketing efficiency level of $30 \%$, thus it was still categorized to be efficient for the percentage value was still below 50\% (Soekartawi, 2007).

\section{CONCLUSION}

The study showed that marketing cost occurred in the FFB marketing channels in Labuhanbatu Regency. This was due to the location place of the farmer's farms with palm mill and the different types of marketing channel, available to farmers. While the marketing function in marketing operations showed differences in expenditure for this function. As for the marketing efficiency in the marketing channel it was known that the cost marketing was $38 \%$ and had a marketing efficiency level of $30 \%$; thus it was still categorized to be efficient for the percentage value that was still below $50 \%$. The study also found that FFB marketing channels in Labuhanbatu District had eight levels, but this study only confirmed one level, namely the third marketing channel. Therefore, this study proposes that subsequent studies will examine the other seven channels with the same and different topics and problems. The study also appealed to other researchers so they could prove if something else had happened besides factors related to the level of marketing channels in Labuhanbatu Regency.

\section{AUTHOR CONTRIBUTIONS}

Conceptualization: Sumitro Sarkum.

Data curation: Sumitro Sarkum. Novilda Elizabeth Mustamu, Gomal Juni Yanris.

Formal Analysis: Sumitro Sarkum.

Investigation: Sumitro Sarkum, Gomal Juni Yanris.

Methodology: Sumitro Sarkum, Novilda Elizabeth Mustamu, Gomal Juni Yanris.

Project Administration: Sumitro Sarkum, Novilda Elizabeth Mustamu, Gomal Juni Yanris.

Software: Gomal Juni Yanris.

Supervision; Sumitro Sarkum, Novilda Elizabeth Mustamu.

Validation: Sumitro Sarkum, Novilda Elizabeth Mustamu, Gomal Juni Yanris.

Visualization: Sumitro Sarkum, Novilda Elizabeth Mustamu, Gomal Juni Yanris.

Writing -Original draft: Sumitro Sarkum, Gomal Juni Yanris.

Writing-review \& editing; Sumitro Sarkum, Novilda Elizabeth Mustamu, Gomal Juni Yanris. 


\section{REFERENCES}

1. Core estate and smallholder. (2017). Retrieved from https:// en.wikipedia.org/w/index. php?title=Core_estate_and smallholder\&oldid $=781858885$

2. Fadilah, F., Dewi, N., \& Hutabarat, S. (2018). Analisis Pemasaran TBS (Tandan Buah Segar) Kelapa Sawit Perkebunan Swadaya di Koperasi Sawit Jaya Kampung Benteng Hulu Kecamatan Mempura Kabupaten Siak. Indonesian Journal of Agricultural Economics (IJAE), 9(2), 150-160. Retrieved from https://ijae. ejournal.unri.ac.id/index.php/IJAE/ article/view/7727

3. Hamdani, K. (2019). Luhut Binsar: Kelapa sawit potensi perekonomian Kabupaten Labuhanbatu. Retrieved from https://sumut.antaranews. com/berita/205809/luhut-binsar-kelapa-sawit-potensi-perekonomiankabupaten-labuhanbatu

4. Harahap, G., Simanullang, E. S., \& Romadon, M. (2017). Analisis Efisiensi Tataniaga Tandan Buah Segar (TBS) Kelapa Sawit (Study Kasus : Petani Perkebunan Inti Rakyat Desa Meranti Paham Kecamatan Panai Hulu, Kabupaten Labuhan Batu). Wahana Inovasi: Jurnal Penelitian Dan Pengabdian Masyarakat UISU, 6(2), 11. Retrieved from http:// penelitian.uisu.ac.id/wp-content/ uploads/2017/09/11.-Gustami-Harahap-dkk-vol-6-no-2-des-2017.pdf

5. Ismail, R., Haryono, S., Harahap, I. M. S., \& Manurung, R. (2020). Tauke and Emotional Network Model in Oil Palm Marketing: Getting Fresh Fruit from Smallholders in Indonesia. Journal of Southwest Jiaotong University, 55(4). Retrieved from http://www. jsju.org/index.php/journal/article/ view/71

6. Naibaho, P. M., \& N, H. (2019). Rekapitulasi Penetapan Harga TBS Kelapa Sawit. Retrieved from http://disbun.sumutprov. go.id/harga_komoditi/web/ index.php? $r=$ site $\% 2$ Flaporanmingguan\&id $=142$

7. Nasution, A. (2016). Bisnis Agen Pembayar Surat Pesanan (SP) Pada Rantai Tataniaga Tandan Buah Segar Kelapa Sawit (TBS) Ke Pabrik di Kabupaten Nagan Raya. Bisnis Tani, 2(1), 8-16. Retrieved from http://jurnal.utu.ac.id/jbtani/article/ view/530/442

8. Noor, D. A. (2013). Analisis Pemasaran Tandan Buah Segar Kelapa Sawit di Kecamatan long Ikis Kabupaten Paser. Jurnal Ekonomi Pertanian Dan Pembangunan, 10(1), 35-42. Retrieved from http://agb. faperta.unmul.ac.id/wp-content/ uploads/2017/04/jurnal-vol-10-no1-dedy-adhan.pdf

9. Nugroho, A. E. (2015). Analisis Pemasaran Tandan Buah Segar Kelapa Sawit Di Kabupaten Kutai Kartanegara (Studi Kasus Pada Petani Swadaya Kecamatan Muara Muntai). Jurnal Magrobis, 15(2), 47-70. Retrieved from http://ejurnal. unikarta.ac.id/index.php/magrobis/ article/view/152/135

10. Pinem, L. J., Safrida, \& Nasution, M. P. (2018). Analisis Saluran Dan Margin Pemasaran Kelapa Sawit di Desa Tenggulun Kabupaten Aceh Tamiang. Agriprimatech, 1(2), 17-22. Retrieved from http://jurnal. unprimdn.ac.id/index.php/Agriprimatech/article/view/488

11. Pratama, A., Eliza, \& Tety, E. (2016). Analisis Saluran Pemasaran Tandan Buah Segar (TBS) Kelapa Sawit Pada Petani Swadaya di Desa Simpang Kelayang Kecamatan Kelayang Kabupaten Indragiri Hulu. Jurnal Ilmiah Pertanian, 12(2), 1-9. Retrieved from https://www.neliti. com/publications/97062/analisissaluran-pemasaran-tandan-buahsegar-tbs-kelapa-sawit-pada-petaniswaday

12. Rahmanta. (2017). Analisis Pemasaran Kelapa Sawit di Kabupaten Labuhan Batu Selatan. Jurnal Agrica Ekstensia, 11(1), 32-38. Retrieved from https://polbangtanmedan.ac.id/upload/upload/jurnal/ Vol\%2011-1/05\%20RAHMANTA\%2017.pdf

13. Sirait, M. T. (2020). Analisis Tataniaga Kelapa Sawit (Elaeis guineensis Jacq.) (Studi Kasus: Kecamatan Kualuh Selatan Kabupaten Labuhanbatu Utara). Agriprimatech, 3(2), 74-83. Retrieved from http://jurnal. unprimdn.ac.id/index.php/Agriprimatech/article/view/924/692

14. Soekartawi. (2007). e-Agribisnis: Teori Dan Aplikasinya. In Seminar Nasional Aplikasi Teknologi Informasi 2007 (SNATI 2007).
15. Statistic Perkebunan Prov. SU (2019). Data Luas Areal, Produksi dan Produktivitas Perkebunan Rakyat Tahun 2019 Komoditas Kelapa Sawit. (2019). Retrieved from http://disbun.sumutprov.go.id/statistik/web/index. php? $r=$ site\%2Flaporan-komoditi\& tahun $=2019 \&$ kabupaten $=14 \&$ kom oditas $=2$

16. Subagyo. (2019). Asosiasi petani beberkan penyebab harga TBS sawit anjlok. Retrieved from https://www. antaranews.com/berita/946575/ asosiasi-petani-beberkan-penyebabharga-tbs-sawit-anjlok

17. Sumartono, E., Badrudin, R., \& Suryanty, M. (2018). Analisis Pemasaran Tandan Buah Segar Kelapa Sawit di Kecamatan Putri Hijau, Kabupaten Bengkulu Utara. AGRARIS: Journal of Agribusiness and Rural Development Research, 4(1), 28-35. https://doi. org/10.18196/agr.4157

18. Sumiati, Rusida, \& Idawati. (2017). Analisis Saluran Pemasaran Kelapa Sawit Di Desa Baku-Baku Kecamatan Malangke Barat Kabupaten Luwu Utara. Journal TABARO Agriculture Science, 1(1), 38-50. Retrieved from http://ojs unanda.ac.id/index.php/jtas/article/ view/13/14

19. Susanti, A. A., \& Waryanto, B. (Eds.). (2018). Agricultural Statistic 2018. Center for Agricultural Data and Information System, Ministry of Agriculture Republic of Indonesia.

20. Tety, E., Maharani, E., \& Deswita, S (2013). Analisis Saluran Pemasaran dan Transmisi Harga Tandan Buah Segar (TBS) Kelapa Sawit pada Petani Swadaya di Desa Sari Galuh Kecamatan Tapun Kabupaten Kampar. Pekbis Jurnal, 5(1), 13-23. Retrieved from https:/ejournal. unri.ac.id/index.php/JPEB/article/ view/1477

21. Wulandari, \& Salman. (2014) Hubungan Patron-Client Dalam Pemasaran Tandan Buah Segar (TBS) Kelapa Sawit di Desa Hangtuah Kecamatan Perhentian Raja Kabupaten Kampar. Jurnal RAT, 3(3), 501-510. Retrieved from http://jurnal2.webuir.com/index. $\mathrm{php} / \mathrm{mydoc} 8 /$ article/view/304/247 